\title{
Creating Brand India: Strategies, Issues, and Challenges
}

\section{Alok Chakrawal and Pratibha Goyal}

\author{
" Brand India has to identify its core product") \\ identity... we have to start looking at what we \\ want to stand for.
}

\author{
Kurush N. Grant \\ Former Executive Director of ITC
}

\begin{abstract}
Just like a product, person, or institution, a country also has an impression in the minds of people. A brand distinguishes the product of one seller from those of the others. With the Indian Prime Minister's recent call to "Make in India", brand building is receiving more attention and momentum in the country. India is the largest democratic country with the highest GDP, and it is becoming a favourable destination for the global investment giants. But, despite various strengths and successes in image building, the country faces challenges in creating a sustainable, conducive environment for making India a production hub of the world. Bureaucracy, corruption, delay in clearance of business proposals, ethical standards and work culture, tax reforms, political interventions, socio-economic barriers, regionalism, etc. are some of the challenges that must be coped with. This article examines these various issues and challenges that must be overcome in creating Brand India.
\end{abstract}

\section{Introduction}

A person, an institution, or even a country leaves an impression in the mind of perceiver. This impression reflects the brand - what distinguishes one person, institution, or country from another. In India and beyond, country-level brand building has been receiving significant attention ever since Indian Prime Minister Narendra Modi's 2014 call to "Make in India" (DIPP, 2016). The initiative is designed to encourage multi-national and national companies to manufacture their products in India, thereby transforming the country into a global design and manufacturing hub. Make in India has became "a rallying cry for India's innumerable stakeholders and partners" (DIPP, 2016) and is a key aspect of the country's future brand. Thus, it is quite pertinent to understand India's image in the minds of the citizen of India and other nationals in the context of the present economic system.

Even in 2011, Kurush Grant, Executive Director of ITC, recognized that "like all successful brands, India as a brand, too, should stand for being a great product in itself. Also, the country and its people have to understand what India symbolises" (Sarkar, 2011). But, if we wish to answer the call to Make in India, we must ask: what is India's brand now? What impression is created in the minds of others when thinking of India today?

In this author's view, a negative impression of India has been created in the minds of foreigners because of perceptions of, for example, poor foreign policies, reports of dishonesty in political parties, unstable relations with neighbouring countries, corruption in the country's administration, and limited trade and cultural relations with the rest of the world (particularly China and fast-growing countries in the region). Even in this age of fast electronic communication and the Internet, where things have become so transparent and easily accessible to people across the globe, people from outside India have a hazy idea about India and its high income disparity, poor health and sanitation conditions, complex caste system, religious and communal conflicts, frenzied approaches of some groups.

India is a diverse country where people live at the greatest of extremes. Around 35 per cent of the urban population lives below the poverty line (SECC, 2015), and yet India is also an atomic power with high-end ballistic missiles and surgical strike capacity. India also has 


\section{Creating Brand India: Strategies, Issues, and Challenges} Alok Chakrawal and Pratibha Goyal

talented people in its information technology sector and many other Indians are working abroad in corporations such as Google, IBM, and Intel. At a projected rate of $7.5 \%$ and rising, India is the fastest growing economy in the world (Gil Sandar, 2015). It is indeed time to remake India's brand.

This article elaborates on the image of India, as seen from the inside and outside, with the aim of understanding Brand India today and what brand-related challenges must be faced if the Make in India initiative is to be successful.

\section{Understanding Brand India}

Top better understand Brand India and to evaluate its chances for success, we considered the following nine factors, which we consider important based on our reading of the relevant literature:

1. GDP share as share of the world economy: At $6.83 \%$, India ranked third among G20 countries in 2014 (Quandl, 2015).

2. Growth rate of GDP: As mentioned above, India is now the world's fastest growing economy (Gil Sandar, 2015). And its GDP growth since 2012 is further highlighted by declines in the other four BRICS countries (Brazil, Russia, China, and South Africa) over the same time period (World Bank, 2016). This growth in GDP is fueled by increasing contributions from services and industry relative to agriculture, which has fallen from over $50 \%$ of GDP composition in the early 1950 s to less than $15 \%$ in the early 2010 s (Planning Commission, 2014). This shift away from agriculture to services and industry is a sign of a developing economy.

3. Investment destination: In the ranking of most attractive destinations for investment, India is ranked first among global investors according to Ernst and Young's India Attractiveness Survey (Ernst and Young, 2015) and is ranked third (behind the United States and the United Kingdom, and just ahead of China and Germany) according to its Capital Confidence Barometer (Ernst and Young, 2016).

4. Political system and stability: Among its near neighbours, is considered relatively stable owing to the following factors: i) the absence of military coups in an independent democratic India; ii) its multi-party political system with a national and regional layer; iii) its strong and active judiciary system that has a degree of control over the country's functionary machinery; iv) its effective legal system with a degree of transparency; checks and balances on political system by non-governmental organizations (NGOs); and v) vigilant public participation in political activism.

5. Corruption perception: Despite all judiciary strength and peoples' active participation in political activism, corruption is common in India, which is ranked 76th among 168 countries in terms of perceived corruption (Transparency International, 2015). It seems that every day, Indians hear about new methods of corruption innovated by Indians. However, if there are silver linings to be found, they are that these revelations of corruption are possible only because there is now a system to control and prevent; that India ranks favourably among its nearest neighbours; and that its rankings are improving.

6. Global presence of Indian corporates: Indian companies are striving hard to make their presence globally and have had some significant achievements. However, there are no Indian companies among the top ten Global 500 companies, whereas China has three (Fortune, 2015). The highest-ranking Indian company is the Indian Oil Corporation (IOC) in the 109th position.

7. Indians leading global corporations: Indian workers have good reputations as hardworking, creative, disciplined, and loyal professionals. Accordingly, many large corporations such as Intel, Microsoft, IBM, BMW, Google, Motorola, MasterCard, SanDisk, Nokia, etc. hire talented Indians. In many cases, the global heads of multi-national corporations are of Indian origin (for examples, see Mishra, 2014).

8. Peace index: As per the Global Peace Index (Institute for Economics \& Peace, 2015), India stands in the 143rd position, behind fellow BRICS countries Brazil (103rd), South Africa (136th), and China (124th), but ahead of Russia (153nd). There is much scope for improvement in this area.

9. Black money: In India, "black money" refers to funds earned on the black market, meaning that no taxes have been paid upon such earnings. India may be better in this area than other fast-developing countries, although this is another area where there is scope for improvement. 


\section{Creating Brand India: Strategies, Issues, and Challenges} Alok Chakrawal and Pratibha Goyal

Besides these nine key factors for projecting the brand image of India, there may many more factors to be considered, such as quality of governance and government effectiveness index, literacy rate and employability quality, adaptability quality, and acceptability.

\section{Boosters to Brand India}

A number of initiatives have been launched recently by the Government of India and non-governmental organizations that are likely to give a boost to efforts to develop a strong Brand India:

1. Clean India Mission (swachhbharat.mygov.in): Launched in October 2014, the ambitious "Swachh Bharat Abhiyan" (Clean India Mission) was undertaken to clean and maintain the cleanliness of the country's streets, roads, and rivers and to develop key hygiene infrastructure throughout the country, both to improve the attractiveness of the landscape and improve the health of the citizens.

2. Digital India (digitalindia.gov.in): This vision of this flagship programme of the Government of India is "to transform India into a digitally empowered society and knowledge economy". The programme focuses on three key areas: i) digital infrastructure for every citizen, ii) governance and services on demand, and iii) digital empowerment of citizens.

3. Skill India (skillindia.gov.in): Launched in July 2015, this initiative of the Government of India aims to train over 400 million people in India in different skills by 2022. The initiatives include the National Skill Development Mission, the National Policy for Skill Development and Entrepreneurship 2015, the Pradhan Mantri Kaushal Vikas Yojana (PMKVY) scheme, and the Skill Loan scheme.

4. Make in India (makeinindia.com): Launched by the Government of India in September 2014, Make in India is designed to encourage multi-national, as well as national companies to manufacture their products in India.

5. Startup India (startupindia.gov.in): This initiative aims at fostering entrepreneurship and promoting innovation by creating an ecosystem that is conducive for growth of startups. The objective is that India must become a nation of job creators instead of being a nation of job seekers. Startup India was launched in January 2016.
In the author's view, an increased focus on the following other activities can also play a role in boosting the current and future Brand India:

1. Foreign policy: India's foreign policy is currently focused on improving relations with neighbouring countries in South Asia and on engaging the extended neighbourhood in Southeast Asia and the major global powers.

2. Foreign strategic alliances: Recently, India has engaged in many joint military operations with, for example, China, France, Russia, Sri Lanka, and the United Kingdom .

3. Inviting foreign heads of state: Among other visits, every year on January 26, India invites the head of state of a leading foreign country to be the chief guest at the Republic Day celebration. Recent guests have included the heads of the states from France, the United States, and Japan.

4. Global MoUs and business relations: India is busy in signing important memorandums of understandings (MoUs) in the areas of trade, industry, and the service sector with important countries to encourage economic growth and development in India.

5. Resolving land issues with neighbours: A longpending land issue with Bangladesh was resolved with the efforts of Government of India last year. Such efforts are in full swing for resolving land issues with China, Pakistan, and Myanmar. It is a great image booster element for India in the eyes of foreign countries that India is able to resolve its important land issues with its neighbours in peaceful manner.

6. Strategic balance in strategic strength: India is a nuclear power, having great capability to strike most of the countries in the region. This power gives strategic strength to India to maintain the power balance in the region.

7. United Nations influence: India seeks a permanent seat in the security council of the United Nations, through which it could increase its global influence.

8. Special government attention on brand building: Amongst the leading organizations working on building Brand India is India Brand Equity Foundation (IBEF; ibef.org), a public-private partnership between the Ministry of Commerce and Industry, the Govern- 


\section{Creating Brand India: Strategies, Issues, and Challenges} Alok Chakrawal and Pratibha Goyal

ment of India, and the Confederation of Indian Industry. It aims to effectively present the Indian business perspective and leverage business partnerships in a globalizing market-place. IBEF regularly tracks government announcements in policy, foreign investment, macroeconomic indicators, and business trends.

\section{Challenges in Creating Brand India}

Taking into account the backdrop of initiatives and activities described above, there is much work being done and many challenges to be overcome in building Brand India. And, like a global product, building a country's brand cannot be done overnight or without help. There has to be a comprehensive effort to be initiated from the government as well as from the entrepreneurs and corporate entities of a nation. Some of the key challenges that must be overcome by these groups are described below:

1. Bureaucratic hassles: India runs under basically the bureaucratic system established by the British almost one and a half centuries ago. Changes have been made, but many reforms are still needed to reduce the frequency and severity of bureaucratic "hassles". It has happened many times that large investors have pulled back from India due to intolerable delays in the project approvals from the authorities. To help improve Brand India, such hassles need to be reduced substantially. Key steps that need to be taken include adding accountability, incentives, transparency, and freedom in decision making, while removing subjectivity, political interventions, and vindictive approaches.

2. Corruption: Corruption is a very common word used in the Indian economy. As we have seen, India has to go a long way to bring down its corruption ranking at a global level. Scams and dishonest behaviour put India's image at stake.

3. Work culture: The work cultures of multinational corporations are often quite different than those typically found in India. Multinationals emphasize performance in an informal setting, with options for employees to work from home, for example, as long as output is maintained. Such practices are now becoming more common in the Indian IT sector, but the overall work culture in India tends to overemphasize physical attendance with not enough attention being paid to output. India needs to modernize its work culture to improve its global image.
4. Quality control: India needs to improve the quality of both exported and domestic goods and services. Quality control contributes to brand building through resource efficiency, increase standards of living, revenue generation, benchmarks, improved work environments, employee satisfaction, and improved moral values and standards. With exports in particular, India becomes better known through its products across the world. Therefore, Indian companies must ensure that international quality standards are being followed and that their products and services support a positive image of India.

5. Flagship concept: India has to take a lead in making and promoting its main products by industry and region. The flagship product concept may give India a big boost in terms of brand building. For example, Japan has a strong brand in technology. Germany is known for its expertise in the automobile sector. Israel is known for new agriculture technology. Similarly, India must decide upon and develop its areas of strength, and its overall brand, as Kurush Grant suggests in the opening quotation of this article.

6. Technology adoption and implementation: Indian managers need to be quick to adopt new technology in the primary sector, industry sector, and service sector. To build Brand India, India companies need to be seen as operating on the forefront of innovation and technology

7. Social and economic welfare: Indian managers have to make sure that the brand building drive does come at the expense of their basic responsibility for social and economic welfare. Corporate social responsibility as a mandatory clause in some Indian companies has helped, but they need to think beyond this threshold of $2 \%$ of net profit. Indian companies have reserves and surpluses that can be used to contribute to the welfare of society.

8. Research and development $(R \& D)$ : India is considered to be a poor investor in R\&D activities. The onus lies upon Indian companies and managers to invest in $\mathrm{R} \& \mathrm{D}$, not only for their own direct benefit but to indirectly contribute to Brand India.

\section{Conclusion}

India has a great legacy and is considered to be one of the oldest economies in the world. In modern times, it can achieve distinction if Brand India is created well. Despite a number of strengths, in India, everything is 


\section{Creating Brand India: Strategies, Issues, and Challenges} Alok Chakrawal and Pratibha Goyal

not as per the aspirations of global business houses. Creating sustainable business environment and making India a production hub of the world is a challenging task. Bureaucracy, corruption, delays in clearance of business proposals, ethical standards and work culture, tax reforms, political interventions, socio-economic barriers, and regionalism are some of the challenges. Nonetheless, India is poised to take advantage of its strengths and overcome these challenges so that it can answer the call to Make in India and promote Brand India.

\section{About the Authors}

Alok Chakrawal is a Professor of Commerce and Business Administration, and the Coordinator of the Internal Quality Assurance Cell (IQAC) at Saurashtra University in Rajkot, India. He holds MCom and PhD degrees, for which he was awarded a Gold Medal upon graduation followed by a Junior Research Fellowship from the University Grants Commission. He is an accomplished international speaker and awardwinning author of academic papers and books, particularly in the domain of stress management. He has been the General Manager and Director of SKSE Securities Ltd., Rajkot, and Controller of Examination of Saurashtra University. He also sits on various boards and committees at national and international levels.

Pratibha Goyal is Professor and Director of the School of Business Studies at Punjab Agricultural University in Ludhiana, India. She received her MBA from Guru Nanak Dev University in, Amritsar, India, and her PhD from Punjabi University in Patiala, India. She began her career as a Deputy Manager of Human Resources in a leading industry. Her immense love for mentoring young minds saw a shift in her career when she joined the faculty of Management in Punajbi University, Patiala, and later in Punjab Agricultural University, Ludhiana. She has been the Principal Investigator of three major research projects of the University Grants Commission and has participated in several national seminars, conferences, and symposia. She is on the Board of Directors of Hero Cycles Limited. She has authored five internationally acclaimed books, besides being Executive Editor of the Effective Management journal. She has published several notable research papers in national and international journals and has guided many scholars in their research projects.

\section{References}

DIPP. 2016. Make in India: About Us. Department of Industrial Policy \& Promotion (DIPP), Ministry of Commerce, Government of India. Accessed May 1, 2016:

http://www.makeinindia.com/about

Ernst and Young. 2015. India Attractiveness Survey 2015: Ready, Set, Grow. New Delhi: Ernst and Young India.

Ernst and Young. 2016. Global Capital Confidence Barometer, 14th ed. London: Ernst and Young.

Fortune. 2015. Global 500. Fortune.com. Accessed May 1, 2015: http://fortune.com/global500/

Gil Sandar, F., Shome, S,. Seth, S., \& Misra, J. 2015. India Development Update: Fiscal Policy for Equitable Growth. Washington, DC: World Bank Group.

Institute for Economics \& Peace. 2015. Global Peace Index 2015. Sydney: Institute for Economics \& Peace.

Mishra, R. 2014. Top 10 Global Operations Head of India Origin. India.com. February 5, 2014. Accessed May 1, 2016: http://www.india.com/top-n/top-10-global-operations-head-ofindian-origin-10763/

Planning Commission. 2014. Databook for Planning Commission. Government of India Planning Commission, December 22, 2014: http://planningcommission.nic.in/data/datatable/data_2312/Dat abookDec2014\%202.pdf

Sarkar, A. 2011. Is India's Brand Image Still Limited in Global Perception? afaqs!: November 2, 2011. Accessed May 1, 2016: http://www.afaqs.com/news/story/32044_AdAsia-2011-Is-Indiasbrand-image-still-limited-in-global-perception

Transparency International. 2015. Table of Results: Corruption Perceptions Index 2015. Berlin: Transparency International. http://www.transparency.org/cpi2015

Quandl. 2015. GDP as Share of World GDP at PPP By Country. Quandl.com. Accessed May 1, 2016: https://www.quandl.com/collections/economics/gdp-as-shareof-world-gdp-at-ppp-by-country

World Bank. 2016. Data: GDP Growth (Annual \%). World Bank. Accessed May 1, 2016: http://data.worldbank.org/indicator/NY.GDP.MKTP.KD.ZG/count ries/1W-IN-CN-RU-ZA-BR?display=graph

Citation: Chakrawal, A., \& Goyal, P. 2016. Creating Brand India: Strategies, Issues, and Challenges. (cc) BY Technology Innovation Management Review, 6(5): 5-9. http://timreview.ca/article/985

Keywords: Brand India, Make in India, innovation, entrepreneurship, government initiatives, challenges, economic growth 